\title{
International Business in Tourism: Media Promotion Perspective in Industry 4.0
}

\author{
Sri Hartati ${ }^{1}$, Atwar Bajari ${ }^{2}$, Rukmi Juwita ${ }^{3}$ \\ School of Business and Management, Bandung Institute of Technology, Indonesia \\ 2 The communication of Science, Padjajaran University, Indonesia \\ 3 Polytechnic Bandung, Indonesia \\ Corresponding Author's : sri.hartati@sbm-itb.ac.id
}

\begin{abstract}
In this era, technologies are fundamental to doing business. The role of technologies in business communications is expanding, and it offers many opportunities. Not only it creates impacts on the internal matters to business, but it also helps to develop social, political, and economic environments. Many technologies internet that is using to promote the business or collaborate with the other platform business. Social media has become one amongst the most-used channel both for private and business communication since the start of this decade, but its various sides might not use within the same manner as individual usage, while for business or company purposes, it becomes a tool to develop the tourism sector. This study aims to know and how the tourism industry business today is in anticipating competition in industry 4.0, how the tourism industry doing business communication, and the media tourism industry to promote business. The tourism industry is the world's largest economic sector, which contributes $10,4 \%$ to global GDP. Three hundred thirteen million jobs or $1 / 10$ jobs in the world supported by the travel and tourism industry, this is equal to $9,9 \%$ of global employment and $1 / 5$ of all global net jobs created in last decade have been within the travel and tourism sector (World and Tourism Council,2018 p.3). The tourism industry is an industry that has a positive impact on improving the economy of countries. In addition to creating employment in the tertiary sector, the tourism industry often promotes growth in the primary and secondary industries regarded as the multiplier effect. Increasing the tourism industry will create new entrepreneurs and a new workforce, and often see as a promotion media used by the tourism industry. To achieve these objectives, the writers use a qualitative methodology by collecting the data from primer and secondary data. This research addressed how the tourism industry can exist in industry 4.0 by using the key reveal determinants found in the analysis.
\end{abstract}

Keywords: international business, business communication, promoting, media, tourism, industry 4.0 


\section{INTRODUCTION}

Globalization is an effort to integrate various countries throughout the world economic, political, or cultural activities in the public and private sectors. The rapid advancement of information technology drove it during the decade. Globalization has become an inevitable phenomenon in national borders to facilitate the movement of people, data, capital flows, goods, and services. Meanwhile, according to Daly (1999), globalization refers to the integration of the global economy from many national economies into the single global economy, primarily through free trade and free capital mobility, but also by smooth or uncontrolled migration. From this understanding, it is understandable that globalization can have both positive and negative impacts on a country. The involvement of cooperation between countries carried out by the government of Indonesia, including the trade cooperation between the ASEAN Economic Community (AEC) and the World Trade Forum (WTO). The benefits that can be obtained by business people from free trade include market expansion that will open up opportunities to increase profits, increase economies of scale, and opportunities for business growth. In the case of the AEC, the engagement could also enhance security and socio-cultural cooperation among the 10 ASEAN member countries. Foreign trade is also a source of foreign exchange, especially if exports are higher than imports.

Tourism in one type of business whose consumers come from local and international customers. The contribution of tourism business to the country's economic growth is quite significant. Recent data shows that the tourism sector can absorb around the workforce 313 million jobs, which equal to $9,9 \%$ of global employment, ,and 1/5 of all global net jobs created in the last decade have been within the travel and tourism sector (World and Tourism Concil,2018.

In Indonesia, the tourism industry contributed to the country's foreign exchange of 15.20 billion USD in 2017 and increased in 2018 to 2018 to 17.00 billion USD, and in 2019 to 20 billion USD. Meanwhile, the number of tourists coming to Indonesia has also increased from 2014 to 2017 from 9 million foreign tourist to 12.6 million, and the target for 2019 will be 20 million foreign tourist. The digital platform becomes a vital tool for promoting tourism destinations. With social media, websites, and mobile applications, various stakeholders promote tourist destinations for different purposes. Both service providers and travelers able to collect much information as they can for their benefit. However, on the other side, there is no guarantee that the tourism promotion campaign will be a success just by having a presence on the Internet. This phenomenon happens because people provided with much information about tourist destinations as people nowadays actively sharing information, experiences, references about product and service.

The organization in charge of promoting tourism has to participate in the Internet actively and engage with people as well. Generally, they create a collaborative platform on the Internet to sharing experiences by delivering quality content. Hence, it allows people who have not been in a tourist destination to get a picture of what is going on there or to simplify; they have to create a live experience for a tourist destination. "Tourism promotion should give consumers knowledge of the existing attractions and infrastructure, differentiating the destination from the competition, 
inspiring confidence and credibility as well as influencing the management of the destination and the purchasing process" (Da Cruz, 2008).

The recent development in technologies for a couple of decades creates many opportunities for communication and the plan to develop social, political, and economic environment. Social media has become one amongst the most-used channel both for private and business communication since the start of this decade, but its various sides might not use within the same manner as individual usage, while for business or company purposes, it becomes a tool to develop the tourism sector.

The phenomenon of technology development gives countless and various ways to support as well as support social and economic environment. Social media created a way for people around the world to communicate with each other about anything, such as services and products, events, news, and corporation that they encountered in their daily life. Social media in promoting business took approach by combining the traditional way of company to introduce or sell their product by salesman or saleswoman and digitalization, which allows people to have borderless communication without having to meet each other in real life. (W.Mangold and Faulds, 2009).

Hotel is one of the tourism industries, which have an essential role in supporting the tourism industry. The increasing number of tourist will have an impact on increasing the number of dwellings, so the promotion carried out by hotels must be following the characteristics of tourists in the millennial era. As for the media that is currently considered appropriate is digital media. Digital media can reach more and broader tourist without limits

\section{RESEARCH BACKGROUND}

\section{International business communication}

Communications is vital apart from personal benefit, which is also essential for the company. Effective communication can help the business. As stated by Courtland L. Bovee (2013) regarding the effectiveness of business communications has a step: Provide practical information, Give fact rather than vague impressions, Present information in concise, Efficient manner, Clarify expectation and responsibilities, Offer compelling, Persuasive argument and recommendation are the essentials factors for the effective business communication.

Communicating is a necessity in the business world today, a professional cannot express their idea adequately, and it will be difficult for them to reach a desired agreement when operating internationally the role of communication in the global business environment which evolves into intercultural communication and necessary to doing business globally. Companies have to face the reality of an intercultural environment which brings diversity and shortcomings. Without the awareness of this fact, we cannot compete in the market, and there is a possibility of restricted profitability opportunities. (Marcel Pikhart, 2014). The relevant 
literature on the subject, the proposed approach, and the new value of research which is its innovation, as well as the urgency.

As for international business communication activities related to the promotion of business and product (exports) that seek to reach government and the private sector from other countries to conduct business transactions (trade, investment, travel and tourism).The stakeholders in international business communication include communication who come from business circle, whereas communicators usually come from officials of government agencies, business circle and communities in other countries (Darwis Yulandre,2013)

Quality communication is not only a straightforward transmission of data but also getting the same perspective of needs and wishes. It is the responsibility of professional workers in the tourism industry to make sure that the information provided is accurate, which is influenced by the different impressions of feedback received from outside. Tourists have subjective interpretations and perceptions in their beliefs, but at the same time, they have to come clear to their preferences in order to avoid confusion or ambiguity in receiving requested services.

For the past two decades, the art of managing global communications developed gradually. Most business communication textbook wrote by expert such as Hanna and Wilson (1998), Chaney and Martin (2000), Locker (2000) Thill and Bovee (2002), Adler and Elmhurst (2005) suggest people who in charge in international business communication matter should understand the basic features about culture they aimed to. This action is essential to create efficient communication in the global business environment. The communicators also need to consider the cultural diversity and intercultural awareness within the country such identify the "dos and don'ts," what is appropriate and inappropriate ways to express ourselves and how those are associated with various culture, values, attitudes, group and social setting which involves the international business communicator. In turn, international business communicator deals with issues supported by comprehensive, realistic information. Issues that often emerge are verbal and nonverbal communications habit, corporate behavior, business, and social norms, and intercultural negotiation mechanism in a different country (see Harris and Moran, 1996). But the truth is culture is complex.

Effective communication is a vital aspect of organization activities, and it applies to any function and position. For example, the global manager needs to plan, organize, monitor, and facilitate all functions to create one dynamic and effectively functioning operational system by effective communication. Cross-cultural communication will happen when two managers from different cultures interacting in both verbal and nonverbal ways for business purposes. Like usual business, the international business also involves negotiation, coordination, and conflict resolution that requires inter-firm communication. A direct meeting will cost time and finances for both parties due to the geographical factor. As a writer doing research for this paper, the writer found only a few research available for inter-firm communication technology in international operations. Most of them focused on the role of communication technology in promoting economic development and analyzed it from a macroeconomic perspective (e.g., Overa2006; Molony, 2009). Some of them focus on micro-level, where the use of information communication 
technology enables more timely market information, lower coordination costs, and trust-based ties between the partners (e.g.Datta,2001; Overa 2006).

The magnitude of the role of the tourism industry on a country's economy is necessary to make an appropriate business communication strategy both to build internal business communication and external business communication. The scope of communication here is refer to the business organization environment. In this environment, there are several interested parties (stakeholders) that influence the organization as a whole. Based on the 'map' of organization, it carried out in the organization internal and external environment. In the internal environment, the organization certainly has internal stakeholders, such as manager and employees. In the external environment, the organization has external stakeholders such as its customers or other organization or company such as distributor and supplier companies

Based on the statement Revista Latina de (2016), the tourism industry becomes one of the pillars of the world's economy because it is constantly to show an obvious impact on the country. The constant growth of tourism is due to various factors, including:

a. Internalization. Because of its existence, tourism is expected to become internalized, but it shows some significant change over the years, such as opening borders between countries and the mutual agreement between countries to erase visa requirements to ease tourist when they are traveling abroad. This action is the country's way of promoting its tourism sector.

b. Corporate globalization. The significant growth over decades in the tourism industry triggered the player in the service and tourism industry to expand more. This created consolidation of the major player in hotels, restaurants, aviation, and transportation corporation in order to provide the tourist with one-stop service.

c. Sustainable tourism. Mass-tourism activities are creating a big impact on the environment, society, and culture. The stakeholders in the tourism industry are aware of the impact of mass-tourism and collaborate to establish policies related to those factors that affecting sustainable tourism as well supported programs to promote sustainable tourism to create well-used resources and significant economic and social development.

d. The emergence of a new business model: The technology development, especially in the Information Technology area, enables tourism companies to market their product directly to people without using the third-party such as travel operators and agents. E-commerce in the tourism industry added with low-cost tourism services changes their consumption and purchasing habits and created independent traveling and direct purchasing.

e. Trend shift: The shifting trend in tourist's way to travel is quite significant. They change from general and "stick to the rule" way of travel to specialized tourism, which caters to the specific needs of travelers. This type of tourist usually more active, desire to blending with the culture of places they visited, which creates a new market segment and tourist destination.

f. The emergence of a collaborative promotion model: In this model, tourist voluntarily gives their impression to tourist destination or services they visited or suggest the unique destination by writing in a travel blog, rating and giving a 
review in mobile application or website or travel blog to create a live experience for the potential visitor.

\section{The Role of Media in Business}

The international business, international business communication, international business transactions, and international management are four things that run together and can't be separated. The international business transaction starts with an exchange between cultures and people with different job functions. This practice changes gradually over a thousand years and specific commercial practices and unique rules until it created a dynamic yet expanding system that we have today. There is a significant difference between domestic and international business transactions. As for domestic transactions, the interaction between customers and traders treated as a part of business management. Meanwhile, international transaction treated the interaction as general management, at least when considering business communication research.

International business transactions have the following characteristics (Kitagawa and Kashiwagi,1999): (1) The possibility of using foreign law as a legal umbrella for business contracts and it might result in more complicated latter action rather than using domestic law. (2) There are possibilities of intercultural understanding issues due to cross-cultural negotiation, conclusion, fulfillment, and conflict resolution. (3) Foreign language issues. (4) Exchange rate risk issues due to differences in the country's currencies and its value. (5) State interventions or policies that might create an unexpected loss of international business deal are more likely to happen in a cross-cultural business agreement. (6) Participation by foreign law institution and procedure such as courts, arbitration/mediation, and lawyer when resolving a dispute between two parties.

Promotion is an essential part of introducing products or services to consumers. Promotional activities will have a positive impact on increasing company operating profit. Promotion as an element of the marketing mix, which has communication and lighting guidelines. Communication mix functions. To foster public awareness about attractions and provide information to the market (target market). Hotels can take several actions in communicating their business. The approach can be made directly or through cooperation with other parties. The approach can directly be made with sales promotion, and the indirect approach can be made using the media.

The development of digital media is currently more advanced, more and more media that can be used by individuals and companies in optimizing their business. This will require individuals and organizations to make changes in communication. Likewise, it is the case with the tourism business world. The higher the use of the media. Hotel is one part of the need for media to make changes to business communication. Media has very high strength in disseminating information and promotions that can affect the people who see it. Likewise, digital media has advantages such as lower promotional costs with high effectiveness. 
Today digital media is a lifestyle for individuals and organizations, with no access limits and can be done anytime and anywhere so that it is beneficial in the promotion of the tourism sector. Changing the use of business communications from conventional to online media is one of the strategies carried out by the hotel. Implementation of strategies online through social media is now widely used by tourism businesses to build relationships with other stakeholders through trust and content that is beneficial to the community. Social media to be accessed anywhere and anytime provides opportunities for businesses to reach a broader audience to promote a variety of existing tourist areas.

In terms of business success, technology and innovation are important. The corporation that follows technological changes and adapts it to their business process, products, and other factors often easily increase their competitiveness. Research and Development activities should prioritize the role of technology-changing and innovation-making. For instance, in order to increase corporate's growth, there should be an enabling atmosphere where the development of the business is taking place. Firms, organizations, or industries, where knowledge is used with great care, prosperity is based on innovation capabilities rather than low cost. Innovation improving in added-value in product or service, country's productivity, and tackle global programs such as environment and scarcity. International competitiveness also triggered by specialization in technological innovation. (Sarıçoban, 2013)

\section{Tourism in Industry 4.0}

Industry 4.0 was first time mentioned in 2011, at the Hannover Fair, Germany. The digital technologies application expand lead to a new industrial revolution era, which becomes an important topic in the last decade. Industry 4.0 defined as the ability of machines to replace manpower in manufacturing and supporting daily needs. This new era is changing the way mass-manufacture produces and applied digital technology in its processor called in terms of "smart way." The experts who attend the fair stated the digital era creates a new way of the production process and new economic concept based on advanced technology strategy. (EBSO, 2015; Robles et al., 2016).

There are three significant innovations in ICT that have influenced the redefinition of the organizational structure in the global tourism industry (Shanker, 2008; Pease \& Rowe, 2005), which are: The development of Computerized Reservation Systems (CRS) as a platform for public information application, The development of Global Distribution Systems (GDS), and The development of the Internet as a new platform for commercial tourism stakeholders.

Industry 4.0 represents an integrated industry vision to apply through the computer, software, and internet. In this context, it also represents a digital revolution in the production process, such as smart factories, automation orders, and robot distribution. In addition, this vision is designed to include all stages of the value chain, starts from the initial idea stage to engineering, production, usage, and recycling stages (Lydon,2016). 
Industry 4.0 has an impact on the business world, where the target consumer has no boundaries. This can change the strategy of business communication carried out into international business communication. According to the US Competitiveness Council, the factors that determine competitiveness changes over time. In the past, "quality and low production costs" were an important determinant of competitiveness, but it is not relevant to today's environment. According to them, there is a small possibility that a country can compete by apply low labor costs, equal access to the market, and using standard production methods over the years. Competitiveness is able to achieve by having innovation capability and creates products and services by the capability of the company. Innovation also not only the tool to ensure an effective way to facilitate interaction between customer and business partners but also ensure the continued success of the tourism market. (Čavlek,2006).

Hotel is one of the tourism industries that must make changes to its business communication strategy. Business communication strategy carried out, in this case, is in the form of promotion using digital media or online media. In the travel structure, we know Hotel is a part of the accommodation service for tourists so Hotel should make a linkage to another part of the travel structure.

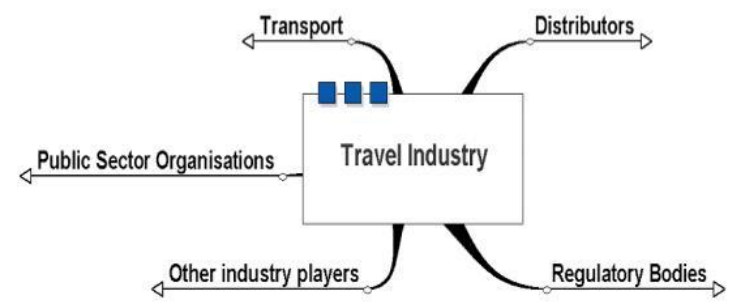

Picture 1: Tourism structure

Development of applications that provide regional tourism information that includes travel cost, entrance fees, nearby lodging, and other information can also be a surefire strategy in optimizing digital marketing. The effect of industry 4.0 in the business sector are defined in three main factor: integrated and digitalization of vertical and horizontal value chains, digitalization of product and services, creation of digital business models, and customer relations.

\section{METHODOLOGY}

Methodology in this research is a case study and then using descriptive analysis. Data collected from primer and secondary data. The unit analysis is a Hotel at West Java, Indonesia. The interview is one technique to get current information about the media to promote a Hotel. 


\section{RESULTS AND DISCUSSION \\ Social Media to Promoting Business Hotel}

According to Rob Torres (2017), the Managing Director of Google, starting from 2017, there will be another 1 billion people coming online and mobile device is the only source to connect to the Internet. Nevertheless, a growing mobile phone user population remains strongly opposed to the slow pace of mobile development that we see through the small travel business. He mentioned that it is now up to travel companies to become mobile-phone oriented because they have the responsibility to global mobile users to both boost the basic experience in terms of internet speed and usability and taking advantage of mobile device's capabilities. The media can use for personal and organization, especially hotels. District Jatinangor as a little city in Sumedang West Java, but we can see there are many hotels, apartments, apartcoss, and something like this (dormitory for student). So, they should be a competition to get many guests. For these cases, Manager Hotel X said; we should make a good strategy if we want sustainable.

In developing the hotel business, many strategies are carried out, especially in promoting the hotel to consumers from abroad. Some of the strategies used are to use social media, which is widely used when establishing cooperation with large business platforms and having more extensive users. Based on interviews The social media used by Hotel $\mathrm{X}$ are Instagram, WhatsApp, and Facebook. This social media, according to Hotel X Manager, is more effective and efficient in promoting hotels. However, this media is limited to the number of followers, so there are still consumer limitations. Hotel $\mathrm{X}$ is located at Raya Jatinangor street. Sumedang, West Java. This hotel has been around for a long time and until now still survives and is able to compete with new and more modern hotels in terms of design. The number of guests staying at Hotel X in the last three months, from July to October 2019, amounted to 2210 people. The number of guests staying will increase if the graduation season, especially IPDN graduation events. For the spread of guest hotel described in the table below:

Table .5.1 Guest Hotel X on July- October 2019 (Data Analysis)

\begin{tabular}{|l|l|c|l|}
\hline NO & Month & $\begin{array}{c}\text { Guest } \\
/ \\
\text { Perso } \\
\mathbf{n}\end{array}$ & Reservation \\
\hline 1 & July & $\begin{array}{c}59 \\
7\end{array}$ & $\begin{array}{l}\text { Traveloka,Agoda,Pegipegi.com,rajakamar, } \\
\text { sales, Instagram }\end{array}$ \\
\hline 2 & August & 9 & $\begin{array}{l}\text { Traveloka,Agoda,tiket.com,pegipegi.com, } \\
\text { hotel sales }\end{array}$ \\
\hline 3 & $\begin{array}{l}\text { Septem } \\
\text { ber }\end{array}$ & 0 & Traveloka,Agoda,pegipegi.com, hotel sales \\
\hline 4 & $\begin{array}{l}\text { Octobe } \\
\text { r }\end{array}$ & 4 & Traveloka,Agoda,pegipegi.com, hotel sales \\
\hline & Total & 2.21 & \\
\hline
\end{tabular}


Based on the table above, the higher Hotel guest in August, namely 689 guests. The increasing number of hotel guests because in August there are many events on Campus, namely IPDN graduation. The increasing number of guests due to the Hotel strategy to collaborate with Online Travel Agent (OTA). This strategy is proven to can increasing guest hotels. Online Travel Agents that have collaborated with Hotel X, namely Traveloka, Agoda, pegipegi.com and tickets.com, and rajakamar. The collaboration with OTA has succeeded in increasing the number of guests staying by $60 \%$. This hotel states that the media is very influential towards guests who are staying overnight. Other reasons delivered by Hotel X Managers at this time the public needs to use an online compilation of hotel bookings. This is also adapted to the 4.0 era or the new era apart from the use of digital technology.

Based on the results of the interview with the General Manager of Hotel X about the strategy obtained by his hotel, it was obtained about the methods obtained so that his hotel was in demand by guests who would stay at Jatinangor by collaborating with all parties such as:

1. Local Government

2. Private parties and companies

3. Companies that already have a Digital Business Platform

4. Sales Promotion

5. Tourism conscious community

The types of guests staying at Hotel X, namely: (1) Domestic Tourists; guests who stay are from local tourists who travel for business or leisure.(2)FITS (Free Independent Travelers): guests who stay personally. (3) GITs (Group Inclusive Tours): Guests who stay at this X Hotel together are on a tour or work visit and (4) Regular Guest: Guests who stay overnight without making a reservation in advance

Guests staying at Hotel $\mathrm{X}$ are from all parts of Indonesia, very few guests or tourists from abroad Jatinangor. This data is obtained from secondary data submitted by the Hotel X Reservation. Many guests are from within the country because Hotel $\mathrm{X}$ is near to IPDN, IKOPIN, and ITB campus, where students come from all provinces in Indonesia.

\section{CONCLUSION}

Based on research analysis, the Internet, especially social media, become the main platform for corporate and individuals to fulfill their daily communication needs. Using social media is vital for promoting business to reach the international 
market. Blogs, micro-blogs, social networks, video file sharing, and forums for discussions are various types of Internet products in terms of communication and sharing information, but not every single platform is suitable for specific communicative purposes. Our analysis showed that all forms of Social Media that hotels used for doing business communication with direct communication like using the blog, Instagram, Facebook, and collaborating with the digital platform such as Traveloka, tiket.com, Agoda, and pegipegi.com. Its platform has a remarkable impact on increasing hotel guests.

From the discussion above, it can be concluded the digital media should continue to be optimized to support tourism marketing strategies because, with digital media, it is expected to help increase the income of the tourism sector, especially for regional income itself. So that remote areas that have hidden tourism potential can be more independent and better known by local and foreign tourists. The use of technology as a medium to collect information is now supported by the existence of social media, which enables interactive communication. Technology development also enables the delivery of exciting content in the form of text, images, audio, and video that can provide clear information about the products or services. No exception, social media is also widely used by the tourism industry.

\section{BIODATA}

Sri Hartati.,SE.,M.Si is a lecturer of the School of Business and Management, Bandung Institute of Technology" Bandung, West Java, Indonesia. She has a research interest in Entrepreneurship, Small Medium Entreprises, Tourism Business, and international business communication.

Dr.Atwar Bajari.,M.com is a lecturer of Communication of science, Padjajaran University, Bandung, West Java Barat, Indonesia. He is teaching in Communication and Research Methodology.

Rukmi Juwita SE.,M.Si is a lecturer at Poltekpos Bandung,West Java,Indonesia.

\section{REFERENCES}

Chaney, L.H. and Martin, J.S. (2000), Intercultural Business Communication, Prentice-Hall, Upper Saddle River, New Jersey, NJ.

Cristian Chelariu Sawyer.(2014).Communication technology in international business-tobusiness relationships Business School, Suffolk University, Boston, Massachusetts, USA, and Talai Osmonbekov W.AJournal of Business \& Industrial Marketing 29/1 (2014) 24-33.Emerald Group Publishing Limited [ISSN 0885-8624]

Da Cruz, G. (2008). Estrategias de la promoción en la Web. Análisis de destinos turísticos internacionales. Revista Estudios y Perspectivas en Turismo, 17, 156 - 169.

Desak Putu Henny Puspawati, Ristanto. (2018). Strategy Digital Promotion to Tourism Development in Magelang City.Jurnal Jendela Inovasi Daerah. Badan Penelitian dan Pengembangan Kota Magelang .ISSN: 2621-8739 https://jurnal.magelangkota.go.id Volume I No. 2, Magelang, December 2018, Hal. 1-20 
EBSO. (2015) Sanayi 4.0 Uyum Sağlamayan Kaybedecek. Ege Bölgesi Sanayiciler Odas1, Araştırma Müdürlüğü

Harris, P.R., and Moran, R.T. (1996), Managing Cultural Differences: Leadership Strategies for New World of Business, Gulf Publishing Company, Houston

Locker, K.O. (2000), Business and Administrative Communication (International edition), Irwin McGraw-Hill, Boston, MA.

Lydon, B. (2016). Industry 4.0: Intelligent and flexible production: Digitization improves manufacturing responsiveness, quality, and efficiency, In Tech Magazine, May-June 2016, Cover story

Martin, M. (2016) Building The Impact Economy; Our Future Yea or No. Springer International Publishing. Switzerland

M Túñez López, V Altamirano, KP Valarezo (2016): Collaborative tourism communication 2.0: promotion, advertising, and interactivity in government tourism websites in Latin America". Revista Latina de Comunicación Social, 71, pp. 249 to 271.

Meryem Turel1, Elife Akis (2019).Industry 4.0 and Competitiveness. Research Journal and Business Management.Volume 6 Issue 3. pp 204-214

Nevenka Cavlek, 2006. "Travel and Tourism Intermediaries," Chapters, in: Larry Dwyer \& Peter Forsyth (ed.), International Handbook on the Economics of Tourism, chapter 6, Edward Elgar Publishing.

Porter, M. E., Stern, S., (1999). The New Challenge to America's Prosperity: Findings from the Innovation Index, Council on Competitiveness Publication Office, Washington D.C.

Pranee Chitakornkijsil. (2010). Intercultural Communication Challenges and Multinational Organizational Communication. International Journal of

Organizational Innovation

Revista Latina de. (2016). Collaborative tourism communication 2.0: promotion, advertising, and interactivity in government tourism websites in Latin America Comunicación Social \# 071 - Pages 249 to 271 Research Funded | DOI: 10.4185/RLCS-2016-1094en | ISSN 1138-5820 | the Year 2016

Robles, V., Mesko, M. \& Krapez, A. (2016). “A complex view of Industry 4.0”, SAGE Open, April-June 2016, pp. 1-11.

Roong Sriussadaporn. (2006).Department of Speech Communication and The current issue and full-text archive of this journal is available at www.emeraldinsight.com/13527606.htm Cross-Cultural Management: An International Journal Vol. 13 No. 4, 2006 pp. 330-344 \# Emerald Group Publishing Limited 1352-7606 DOI $10.1108 / 13527600610713422$

Sarıçoban, K. (2013). Küresel Rekabette Kümelenme ve İnovasyonun Rolü, Sosyal ve Beşeri Bilimler Dergisi, ISSN: 1309-8012 (online), 94-104

Shanker, (2008); Pease \& Rowe, (2005).Managing international business communication problems at work: a pilot study in foreign companies in Thailand

Thill, J.V. and Bovee, C.L. (2002), Excellence in Business Communication, Prentice-Hall, Upper Saddle River, New Jersey, NJ.

Trends and Issues in the Tourism and Hospitality Industry. (2017).Global Economic Impact and Issues (2017).Trends and Issues in the Tourism and Hospitality Industry.

Yeni Imaniar Hamzah.(2006) Social Media potential as Interactive Promoting to Indonesian Tourism.Research and Tourism. Ministry of Tourism and Craetive Industry. BENEFIT Journal Vol. 10, No. 12006.

Widoyono. (2015).Promotion as One of Effort in Tourism Marketing. Faculty of Economics. The University of Muhammadiyah Surakarta Promotion Digital. 
W. Glynn Mangold and David J.Faulds (2009).Social media: The new hybrid element of the promotion mix Business Horizons.Volume 52, Issue 4, July- August 2009.

\section{Electronic/Internet Source}

https://www.indonesiana.id/read/123366/sosial-media-efektif-sebagai-media promosi-pariwisata\#ZToPEjORVQAVkbCE.99

https://www.indonesiana.id/read/123366/sosial-media-efektif-sebagai-media promosipariwisata\#ZToPEjORVQAVkbCE.99

Torres, Rob (2017), Technology Trends and the Future of Travel. Available at https://medium.com/@WTTC/technology-trends-and-the-future-of-travelc6df8d91a0e9 